JOAL, (JOURNAL, OF APPIIII) LINGUISTIICS ANI) LITIRA'TURE)

Vol. 4 No. 1, 2019

ISSN (print): 2502-7816; ISSN (online): 2503-524X

Available online at https:/ / ejournal.unib.ac.id/index.php/joall/index

doi: 10.33369/joall.v4i1.7384

\title{
STUDENTS' DIFFICULTIES IN TRANSLATING ENGLISH TEXT
}

\author{
${ }^{1}$ Arono; ${ }^{2}$ Nadrah \\ 1University of Bengkulu, ${ }^{2}$ IAIN Bengkulu \\ Corresponding author: arono@unib.ac.id
}

\begin{abstract}
Nowdays, there are many translation problems although software application to assist translation are available. The objectives of this research were to identify types of error in translation, students' difficulties in translating text, and factors which influence students' error in translating in English department of State Institute for Islamic Studies Bengkulu. This research used descriptive quantitative method. The results of this research showed that students' difficulties in translating English text, were elliptical errors (67.29\%), idioms (87.5\%), and textual meaning (73.54). The difficulties of students in translating were lack of vocabulary $(87,50 \%)$, difficult translating Islamic texts $(75,00 \%)$, literary works $(66,66 \%)$, and grammatical issues $(62,50 \%)$. Then, the factors affected students' error in translation were ignorance of ellipsis; unable to identify ellipsis, idiom, and lexical meaning; lack of strategy in translating ellipsis, idiom, and lexical meaning; translating words per word; most students lack a strong background on the content of the text. It was concluded that the students got three types of error in transalation, four points difficulties in translation, and six factors which influence the students' error in translation.
\end{abstract}

Keywords: Translation, difficulties, and English text

\section{INTRODUCTION}

Translation is the transmission of a thought in a language to another language. It is a process which guides from written source language text into target language (Pinchuck, 1977; Wilss, 1982; Newmark, 1991). It is also a bridge to understand the knowledge, science, textual material, and others. Many learners do translation to understand text. However, they have difficulties in translating from English to Indonesia or the vice versa even though software application to assist translation are available. Some learners said that translation is difficult since the materials of translation are not suitable with the need of language learners, the activity of translation is boring, and the learners also lack of background knowledge about linguistic. They may do errors in translating some idioms and some words which are not familiar with their native language because the culture influences 
language's expressions. As it is said by Al-Darawish (1983), general difficulties in doing translation are no two languages are exactly the same in term of phonological, morphological, lexical, syntactic, and semantic features. They are divergent in arrangement of sentences or syntax. That's why students find it difficult in translating of English into the target language

Then, another difficulty is to translate idiomatic expressions from English into the target language. As it is stated by Baker (1992) there are two factors which make idiomatic expression translation in English difficult. First, the translators lack of equivalence of the target language. They do not know the acceptable translation of some words into target language since different languages express different linguistic features. The latter, culture specific idioms are also not easy for the students to translate into the target language. They may refer to specific items to that particular culture of the language. However, according to Komissarov (1985), five aspects should be considered in idiomatic expressions such as figurative meaning, literal meaning, emotive character, stylistic register, and national coloring. Figurative meaning tries to give meaning not based on the basic meaning of the words but imaginative meaning. The translators should be able to assess the figurative meaning in the sentences. Then, literal meaning is the basic meaning or original meaning of the words. To look for the literal meaning is not as difficult as figurative language. Emotive character means that whether the sentences providing positive, negative, and neutral meanings, whereas stylistic register is to notice whether the sentences are very formal, informal, slang or taboo. Last, national coloring means proper nouns of something using nationality. Those five aspects cause difficulty for students in translating.

Some studies related to translation have been reported such as Suksaereseup and Thep-Ackrapong (2009) they show that the translators have problems in reading process of the source text and wrong lexical interpretation. This translation was done by Thai students who translated from English to Thai. Then, Sukmana (2000) also reported in her research that most students of sixth semester of English study program at University of Bengkulu get poor achievement and none of them get good achievement in translating idiomatic expression. Another research was also done by $\mathrm{Al}$ Zu'bi (2018) which maintains that M.A students who take translation program in Yarmouk and Middle east University faced difficulties in translating. It was because their unfamiliarity with political expression and resorting to literal translation.

Moreover, Ibrahim (2017) has conducted research about an investigation of difficulties of translation which faced by Sudanese students in Dongola University. His research aims were to find out kind of students' 
difficulties in translation, introducing pupils' difficulties in detail, and how to overcome the problems. The data were taken from Dongola University consisted of 30 students. Questionnaire was used to take the data of the study. He reported that Sudanese University students in College of Education in the second semester find students' difficulties in translating because of grammatical categories, linguistic level, lexical items, and some differences between source language with the target language.

Whereas, another research also applied in M.A translation students in University of Yarmouk and University of Jordan entitled 'difficulties EFL Jordanian University students encounter in translating English idioms into Arabic. This research claims that EFL students find it hard to translate idioms from English into suitable equivalent Arabic in term of opaque and semi-opaque idioms from context. In detail, it can be showed that the index value of difficulties of appropriate translation was 0,472 . It means that the students get difficulties in translating opaque idioms from English into Arabic. Then, they also face problems in translating semi-opaque idioms with index value of difficulties at 0,742. From this calculation, it demonstrates that the students get difficulties in translating semi-opaque idioms English to Arabic at moderate level. It happened since they lack of knowledge of the target language cultural expressions, the gap between those two cultural languages and lack of attention due to English idioms in translation and English program (Alrishan \& Smadi, 2015).

Furthermore, Kohil (2005) also conducted research about students' difficulties in finding equivalent of translating idiomatic phrasal verbs from English into Arabic. The purpose of her research was to explore how pupils' linguistic competence affects their translation process. In this investigation, twenty five third year students of English department in Mentouri University of Constantine were chosen randomly to respond a written translation test. The result of her research shows that the students make more incorrect compared to correct answer. They also encounter some problems when translating idiomatic phrasal verbs from English into Arabic. These matters are caused by the lack of students' knowledge due to linguistic competence and literal meaning.

However, those studies have not discussed deeply yet about students' difficulties in translating English texts. A considerable some research has investigated due to poor in translating idiomatic expressions. Other also had conducted the study of translation difficulties viewed from grammatical categories, linguistic level, and lexical items. However, there is a little research related to type of error in translation, students' difficulties in translation, and factors which influence students' error in translation in State Institute of Islamic Studies of Bengkulu. Therefore, additional studies on types of error and students' difficulties in translation as well as factors which 
make students' error in translation are needed. The aims of this study are to identify types of error in translation, students' difficulties in translation, and factors which influence students' error in translation in English department in State Institute of Islamic Studies of Bengkulu.

\section{METHODS}

This research used descriptive quantitative method. Gay (2000) said that descriptive research involves collecting data in order to answer questions concerning to the current status of the study. It was used to find out types of error in translation, students' difficulties in translation, and factors which influence students' error in doing translation. The population was sixth semester of English study program and sample of this research was 24 students English study program in State Institute of Islamic Studies of Bengkulu. The data of the research were collected by using test, questionnaire, and interview.

The researchers applied test to identify types of error in translation, questionnaire to find out students' difficulties in translation, and interview to identify factors which influence students' error in doing translation. In collecting the data, the researchers conducted test and then spread questionnaire, and lastly interview the students with the prepared questions. Then, the data were analyzed by using four alternatives options; they were always, often, seldom, and never which proposed by Sugiyono (2007). These alternative options were used for analyzing questionnaire. Meanwhile, in analyzing the test, the researchers used four steps: first, the students' work evaluated one by one; second, the students' translation errors were marked; third, the students' translation errors were grouped based on the types of errors; fourth, and calculating the percentage of errors made by using formula suggested by Sudjana (1989).

\section{FINDINGS}

Based on the research finding, it can be seen from the following table.

Table 1. Percentage of students' errors

\begin{tabular}{clcc}
\hline No & \multicolumn{1}{c}{ Types of errors } & $\begin{array}{c}\text { Number of } \\
\text { total errors }\end{array}$ & $\begin{array}{c}\text { Percentage of } \\
\text { total errors }\end{array}$ \\
\hline 1 & Translating idioms & 420 & $87,5 \%$ \\
2 & Translating ellipsis & 323 & $67,29 \%$ \\
3 & Textual meaning & 353 & $73,54 \%$ \\
& Total Errors & 1096 & \\
\hline
\end{tabular}

From the table above, the most frequent error made by students is translating idioms that occur 420 times which equals to $87.05 \%$ of the total errors. The data of difficulties in translating idioms can be seen from the sentence "Make a long story short". The student's translation "Buatlah cerita itu menjadi singkat", whereas the acceptable translation is "Berbicara langsung 
pada intinya". The students get confused the acceptable answer for the idioms "Make a long story short". Then, it is followed by 73,54\% with 353 number of error for textual meaning. The data shows from the example of the sentence "' the gardener waters the garden twice a day. The water is taken from the river." The student translates the sentence into "tukang kebun mengairi kebun dua kali sehari. Pengairan di ambil dari sungai". The acceptable translation is "tukang kebun mnyiram kebun dua kali seminggu. Air di ambil dari sungai". The student still does not get the acceptable translation for that sentence. Meanwhile, the percentage of translating ellipsis is the lowest percentage at $67,29 \%$ with 323 number of error. It can be seen from the data of the sentence such as "Sinta did not come to my birthday party, and neither did Mike. The student translates into "Sinta tidak datang ke pesta saya, Mike juga". The acceptable answer is "Sinta tidak datang ke pesta saya, Mike juga tidak datang". The student still gets difficult an acepptable answer.

Table 2. Percentage of students' difficulties in translation

\begin{tabular}{|c|c|c|c|c|c|c|c|c|c|}
\hline \multirow{2}{*}{ No } & \multirow{2}{*}{$\begin{array}{c}\text { Type of } \\
\text { Difficulties }\end{array}$} & \multicolumn{8}{|c|}{ Students Frequency in Option and Percentage } \\
\hline & & Always & $\%$ & Often & $\%$ & Seldom & $\%$ & Never & $\%$ \\
\hline 1 & $\begin{array}{l}\text { Lack of many } \\
\text { vocabularies }\end{array}$ & 21 & $\begin{array}{c}87,50 \\
\%\end{array}$ & 2 & $\begin{array}{c}08,33 \\
\%\end{array}$ & 1 & $\begin{array}{c}04,17 \\
\%\end{array}$ & 0 & 0 \\
\hline 2 & $\begin{array}{l}\text { Translating } \\
\text { islamic texts }\end{array}$ & 1 & $\begin{array}{c}04,17 \\
\%\end{array}$ & 18 & $\begin{array}{c}75,00 \\
\%\end{array}$ & 5 & $\begin{array}{c}20,83 \\
\%\end{array}$ & 0 & 0 \\
\hline 3 & $\begin{array}{l}\text { translating } \\
\text { literary texts }\end{array}$ & 2 & $\begin{array}{c}08,34 \\
\%\end{array}$ & 16 & $\begin{array}{c}66,66 \\
\%\end{array}$ & 4 & $\begin{array}{c}16,66 \\
\%\end{array}$ & 2 & $\begin{array}{c}08,3 \\
4 \%\end{array}$ \\
\hline 4 & $\begin{array}{l}\text { The neceesity of } \\
\text { grammar in } \\
\text { translation }\end{array}$ & 15 & $\begin{array}{c}62,50 \\
\%\end{array}$ & 5 & $\begin{array}{c}20,83 \\
\%\end{array}$ & 4 & $\begin{array}{c}16,66 \\
\%\end{array}$ & 0 & 0 \\
\hline
\end{tabular}

In this table, 21 students $(87,50 \%)$ always find difficult to translate since they lack of English vocabularies. For instance, the sentence "the secretary strives to get promotion to be a directur" is translated into 'sekreatris ingin mendapatkan promosi menjadi direktur". The acceptable translation is "sekretaris berjuang untuk mendapatkan promosi menjadi direktur". Then, 18 students $(75,00 \%)$ often find difficult in translating islamic texts. For example in the sentence "two of pilllars of Islam are fasting and pilgrimage to Mecca". The student translates into "dua rukun Islam adalah puasa dan ke Mekkah". The acceptable translation is "dua rukun Isalam adalah berpuasa dan naik haji ke Mekkah". The student find hard to translate pilgrimage to Mecca to acceptable translation. In addition, 16 students $(66,66 \%)$ often feel difficult in translating for literary text. The students find it difficult to translate "the stars danced playfully in the moonlit sky". The student's translation is "bintang-bintang menari dan bermai-main di angkasa". The acceptable translation is "bintang-bintang menari main-main di langit di terangi cahaya bulan". Lastly, 15 students (62,50\%) said that they always get difficulties in translation because of grammatical factor. For 
example in the sentence "Rini is not going to shopping by herself, and her mother is not either". The student's translation is "Rini tidak pergi shopping sendirian, dan ibu juga". The acceptable translation is "Rini tidak pergi belanja sendirian, dan ibu Rini juga tidak pergi sendirian." The student got confuses to get acceptable translation because of grammatical structure of the sentence.

Table 3. Some factors which influence students's error in translation

\begin{tabular}{cl}
\hline No & \multicolumn{1}{c}{ Factors which influence students in translation } \\
\hline 1 & ignorance in term ellipsis \\
2 & can not identify ellipsis, idiom, and textual meaning \\
3 & lack of strategy in translating ellipsis, idiom, and textual meaning \\
4 & still translating word of speech \\
5 & most students lack a strong background on the content of the text \\
\hline
\end{tabular}

Table three showed that there are five factors which influence students' error in translation. They are ignorance in term ellipsis, can not identify ellipsis, idiom, and textual meaning, lack of strategy in translating ellipsis, idiom, and textual meaning, still translating word of speech, most students lack a strong background on the content of the text. Those factors make the students feel difficult to translate the sentences from English to Indonesian. Starting from factor 1 to factor 4 , the example of the sentences have been mentioned in explanantion of table 2. The last factor is the students do not have enough background knowledge about the content of the text since the students can not comprehend certain fields of knowlegde.

\section{DISCUSSION}

The purpose of this study was to identify type of error in translating, students' difficulties in translating, and factors which influence the students' error in doing translation of English students of sixth semester in Islamic Studies of State Institute of Bengkulu.

First is to identify type of error in translating. It can be seen from the finding in the table one above, there are three types of error made by students in translating; they are idioms, ellipsis, and adjustment of textual meaning. Error in translating idioms has the highest percentage at $87,5 \%$ among three types of error in translation. It means that an idiom is the most difficult part for the students to translate. It is happened because idioms cannot be understood from the literal meaning of the words which they are composed; or they are difficult to understand from individual words (Redman, 1997). For instance, the idiom in the sentence" Don't let Keith upset you. He loves laying down the law but nobody takes him seriously." The student answer is "Jangan biarkan Keith mengganggu kamu. Dia suka membohongi hukum tapi tak seorangpun yang menganggapinya serius". The correct answer is "Jangan biarkan Keith membuatmu marah. Dia suka membawa-bawa hukum tetapi tak seorangpun menanggapinya terlalu serius." From this example, it can be 
seen that the student do not realize the underlined words idioms, and he/she translates the sentences word by word in target language. The translation is not equivalent to the target language. Then, another example of idiom is in the sentence "The English grammar test was a piece of cake" the students translate into "tes tata bahasa Inggris tersebut sulit". The correct translation is "test tata bahasa Inggris tersebut mudah". The students also get difficult in translation the sentence "I am really feeling under the weather today". They translate it into "saya merasa cuaca tidak bagus hari ini". The correct translation is "saya merasa tidak sehat hari ini". From this example, it can be seen that the students do not realize the underlined words idioms. The translation is not equivalent to the target language.

The students' difficulties in translation of idioms have been supported by Baker (1992). Baker said that the first difficulty found by the translators in translating idioms was the capability to identify and to differentiate idioms from non-idioms usage. Idioms are sometimes impossible to recognize since modification can be done in idioms and can spread over a clause. This situation makes the students difficult to translate idioms in the target language. It is also supported by Howwar (2013) that idioms are as part of mastering any languages and part of everyday language usage since idioms show linguistic and cultural boundaries which is able to communicate between cultures. Because of the boundary of linguistic and culture may make the students hard to translate the idioms into Indonesian. They may not predict the acceptable answer for the given idioms. It seems clear that idioms in translation are difficult for the students to find the appropriate of their translation.

Another error made by the students is textual meaning which has $13,69 \%$ lower than the percentage of errors in idioms. It can be said that the students still have difficulties in translating phrases. These phrases need adjustment of textual meaning. In this research, the researcher used two short texts which contain 7 phrases in the first text and 3 phrases in the second text. It can be seen from one of part the text such as "Many poor countries have had bad experiences in recent decades when they tried to leapfrog into an industrial economy by importing steel mills and huge manufacturing plants." The student translates the underlined phrase into "mencoba untuk mengulanginya", whereas the acceptable answer is "."mencoba masuk kedalam". From this example, the student's answer has not been acceptable yet with the target language. Most students made error not only in tranalating phrases but also in translating other sentences in the text. As it is supported by Rachmadie (1988) textual meaning is the meaning that is determined by the text. The students should see context of the text in translating that phrase. 
Then, errors are also found in translating ellipsis with the percentagee $67,29 \%$. The researchers prepared 10 sentences which contains ellipsis The students felt difficult to translate the ellipsis. For example, "true stories deal with anger, imaginary one with love". The student's translation is "kisah nyata ada karena kemarahan, yang berimajinasi dengan cinta". The correct translation is " kisah-kisah nyata berkaitan dengan amarah, kisah imajinasi berkaitan dengan cinta". Another example is "in the baseball game, our team scored four homeruns, the other team,only two", The students' answer is "dalam permainan baseball, tim kami memenagkan empat goal, dan tim lainnya dua gol". The corrrect translation is "dalam pertandingan bisbol, tim kami mencetak empat goal, tim bisbol yang lainnya mencetak dua gol". In this example, noun is omitted in underlined sentence. It made the students confuse in translating them. It is suggested for the students to repeat the noun to get acceptable translation in target language. It is stated by Rachmadie (1988) ellipsis is a structural relation which one linguistic is omitted. The word omitted in the sentences may correct grammatically, but the students do not fully understand the sentence meaning because of that omission. It also contents that ellipsis is a case in which a structural gap is found or is completed by reference of related structure (Halliday \&Hassan, 1976). This condition makes the students get confused how to translate ellipsis in appropriate answer.

Second, to identify students' difficulties in translation can be seen from the table two. Most students find it difficult in doing translation because of lack of vocabularies. It can be seen from the table, twenty one students always find it the most difficult in translating because they need many vocabularies with percentage $87,50 \%$. It is only two students at percentage of $08,33 \%$ said that they are often difficult to translate because of vocabularies, whereas only one student said that he seldom find it difficult to translate because of new vocabularies. The next difficulty is in translating Islamic text with 18 students $(75,00 \%)$ often find it difficult. Next, it is merely one student $(04,17 \%)$ said that he always gets difficulties in translating Islamic text, while five students said that they are seldom in getting hard to translate Islamic text. As Ma'mur (2006) asserts that students' problem in translating Islamic text because of some reasons such as prophetic words do not have their appropriate meaning in English and some Islamic texts are perhaps not well written since they are not written by writers of native language.

Moreover, it can be also seen from table two that literary texts are also difficult for the students to translate. Two students $(08,34 \%)$ assert that they are always difficult to translate literary text. Then, sixteen students at $66,66 \%$ said that they often find difficult in translating literary texts. Meanwhile, four students $(16,66 \%)$ seldom find it difficult in translating literary text, two students say that they never get difficult in translating 
literary texts. In this part, they should know the meaning behind the words which are written by the writer. Newmark (1991) said that literary texts contain figurative meanings which are difficult to translate to Indonesia or vice versa. It is also supported by Apostolatu and Apostolatu (2012) in their paper that literature texts were problematic since they involve translating the metaphorical and figurative meaning of the texts. The other difficulty in translation is grammar. Fifteen students $(62,50 \%)$ always find it difficult to translate because of grammar. Five students at $20,83 \%$ often find it difficult to translate because of translation, and only four students seldom get difficult in translation because of grammar. They do not know how to translate the sentences or the text well since they lack of mastering grammatical pattern of a language. When the sentences are complicated and long, they are hard to translate them well, (Fahrurrozi, 2003). As it is proven by Ibrahim (2017) in his research that students got difficulties in translating because of grammatical categories, linguistic level, lexical items, and some differences between source language with target language.

Lastly is to identify factors which influence the students' error in translation. It can be seen in the table three, there are five factors which made the students' error in translating. The students ignore term of ellipsis since they do not understand them. They also cannot identify ellipsis, idiom, and textual meaning. They have tried to translate them carefully, but they still got the unaccepteble translation. As stated by Sukamana (2000), the students got difficulties in translating idioms because they don't kow the acceptable translation of them.

After that, they lack of knowledge of strategy in translating ellipsis, idiom, and textual meaning in order to get equivalent meaning in the target language. Moreover, they translate the text word by word in translation process. They do not pay attention to the whole context of the text. They also do not have strong background knowledge about the context of the text given to them. It is supported by Newmark (1991) that in translating some texts, the students are influenced by translator knowledge of another language and knowledge of the context of the text. Besides, accurate strategies are not used by the students to get approriate translation. They sometimes focus on word per word translation and they also often use paraphrasing and cultural substitution strategies to get acceptable translation (Meryem, 2010). This condition makes them difficult to figure out the acceptable translation in target language.

Based on the discussion above, it is suggested for furher studies dealing with students' strategies in facing difficulties in translation ir order to have suitable translation in target languge. 


\section{CONCLUSION AND SUGGESTION}

Translation is one difficult subjects faced by the students of English study program in State Institute of Islamic Studies of Bengkulu. The students have made three kinds of error namely of idioms, ellipsis, and textual meaning in translation. Besides, they find it difficult in translation because they lack of vocabularies, are difficult to translate Islamic texts, get difficulty in understanding literary texts, and are difficult to translate the texts because of grammar. They are also influenced by some factors which made them error in doing translation. Those factors are ignorance in term ellipsis, can not identify ellipsis, idiom, and textual meaning, lack of strategy in translating ellipsis, idiom, and textual meaning, still translating word of speech, most students lack a strong background on the content of the text. It is recommended for the students in translating the texts to see and understand the context of the texts before translating, to know the form of the pattern of the sentences in the texts, to study literary texts by consulting with the lecturers, to know the meaning of them, and to find better strategies in translating by reading some books or other sources related to strategies of translation.

After analyzing the data, there are 4 types of grammatical cohesion found in the data namely reference, conjunctive system, substitution and ellipsis. In relation to the realization of grammatical cohesion, it can be seen that the reference $(43 \%)$ which was the predominant of grammatical cohesive features used by in Thai Cave Rescue news in the international newspapers compared to other types.

In the reference, it was found that personal reference $(89 \%)$ was the dominant one followed by a comparative reference $(9 \%)$ and demonstrative reference $(2 \%)$ which meant that every types or reference was found in this research. While conjunction (42\%) took the second position with additive $(48 \%)$, Temporal (21\%), Adversative (9\%), Matter (6\%), Clarifying (5\%), Conditional (5\%), Varying (4\%) and Cause (2\%) which meant that all types of conjunctions were not found in this study but only a few. The third one was substitution (10\%) with nominal substitution $(81 \%)$ and verbal substitution $(19 \%)$ which meant that clausal substitution was not found in this research. Then, ellipsis took the fourth or last position with the clausal ellipsis $(84 \%)$ and nominal ellipsis $(16 \%)$ which meant that verbal ellipsis was not found in this research. Because this research is only focused on written text, it is also suggested that the further researchers are able to examine the grammatical cohesion in the spoken text. It can be used to explore deeper the use of ellipsis and substitutions since those types of grammatical cohesion are seldom found in the written text. 


\section{REFERENCES}

Alrishan, A \& Smadi, O. (2015). Difficulties EFL Jordanian university students encounter in translating English idioms into Arabic. Journal of Education and Practice.6 (10). 124-133

Al-Darawish, H. (1983). Arabizing university education in Arabic, Jerusalem, Arab studies society. Cited in Hamdallah, R.,Problems and approaches to translation with reference to Arabic. Language and translation.J.King Saud University, 10. 23-38

$\mathrm{Al} \mathrm{Zu'bi,} \mathrm{I.} \mathrm{(2018).} \mathrm{Difficulties} \mathrm{that} \mathrm{M.A} \mathrm{students} \mathrm{encounter} \mathrm{in} \mathrm{translating}$ political expression from his majesty King Abdullah's our last Best Chance. Middle East : Middle East University. Retrived on 20 January 2018 from https://meu.edu.jo/libraryTheses/5870a6efa6fcb_1.pdf

Apostolatu, R.C. \& Apostolatu, I. (2012). Lingustic and cultural issues in translating negation in literary texts: A case study, Mourning becomes electra, by Eugene O'neil. Paper presented at international conference: Paradigms of ideological discourse. https:// www.slideshare.net/AleeenaFarooq/problems-in-translating

Baker, M. (1992). In other words; A course book on translation. London: Routledge

Fahrurrozi. (2003). Teknis praktis terjemahan. Yogyakarta: Teknomedia Yogyakarta.

Gay, R.L. (2000). Educational research. London: Merril Publishing Company

Halliday, M., \& Hssan, H. (1976). Cohesion in English. London: Erward Arnold.

Howwar, M. (2013). Seeking the nature of idioms : A socio cultural study in idiomatic English and Arabic meaning. International Journal of Scientific and Research Publications,3(2), 1-3

Ibrahim, M.A.E. (2017). An investigation of difficulties of translation that face Sudanese university students: A case study of College of Education, Dongla University. International Journal of Social Science and Humanities Research. 5(3).587-601.

Kohil, H. (2009). Investigating problems in translating English idiomatic phrasal verbs into Arabic. M.A Thesis. Mentouri Univerisity of Constantine, Algeria

Komissarov, V. (1985). The practival value of translation theory. Babel. 34(1), 280-2813

Ma'mur, I. (2006). Pijar-pijar pemikiran bahasa dan budaya. Jakarta : Diadit Media.

Meryem, M. (2010). Problems of idioms in translation, case study: First year master. Mentouri University: Constantine.

Newmark, P. (991). About translation. Australia: Multilingual Ltd. 
Pinchuck, I. (1997). Scientific and technical translation. London: Andre Deutsch.

Redman, S. (1997). English vocabulary in use pre-intermediate and intermedidate. Jakarta: Erlangga.

Sudjana, N. (1989). Penelitian hasil proses belajar mengajar. Bandung: Remaja Rosdakarya.

Sugiyono. (2007). Metode penelitian pendidikan. Bandung : Alfabeta.

Sukmana, W. (2000). The English - Indonesian translation skills. University of Bengkulu: Unpublished thesis.

Suksaereseup, N. \& Thep-Ackrapong, T. (2009). Errors found in translation from English to Thai. Translation Journal. 13(1).

Wilss, W. (1982). The science of translation: Problems and method. Tubigen, Germany: Gunter Narr Verlag. 